\title{
NOISE AS AN EXTERNAL EFFECT OF TRAFFIC AND TRANSPORTATION
}

\author{
Slobodan M. Starčević ${ }^{a}$, Nebojša J. Bojović ${ }^{b}$ \\ ${ }^{a}$ Ministry of Defence of the Republic of Serbia, \\ Cabinet of the Minister of Defence, Belgrade, Republic of Serbia \\ e-mail: slobodan.starcevic@mod.gov.rs, \\ ORCID iD: 10http://orcid.org/0000-0002-7185-3698, \\ ' University of Belgrade, Faculty of Transport, Belgrade, Republic of Serbia, \\ e-mail: nb.bojovic@sf.bg.ac.rs, \\ ORCID iD: (Dhttp://orcid.org/0000-0001-5600-3807
}

DOI: 10.5937/vojtehg64-9131

FIELD: logistics, transport

ARTICLE TYPE: Professional Paper

ARTICLE LANGUAGE: English

\section{Summary:}

The paper deals with the basic concepts and characteristics of external effects of traffic and transport, with an emphasis on the impact of traffic noise as one of the main external effects of transport nowadays. The main negative impacts of traffic noise on human life and social activities are given as well as the causes of elevated levels of noise from road, rail and tram traffic. In addition, the paper provides a review of the common measures that can be applied to reduce the impact of noise generated as a result of traffic and transport activities. In the end, we made a short review of the current situation regarding the impact of traffic noise in the Republic of Serbia and the Serbian Armed Forces.

Key words: traffic, noise.

\section{Introduction}

The rapid development of industry and technology has undoubtedly led to a rise in the standard of living, which results in increased traffic activity. This is primarily related to passenger and freight road transport, but certainly to rail, water and air transport as well. However, as a part of comprehensive technical development, problems related to the preservation of the environment also increased. The increasing concentration of traffic activity in urban areas has the effect of endangering the working and living environment. The influencing factors are: pollution of air and working environment, noise and vibration, traffic accidents, uncontrolled discharge of harmful and hazardous substances, traffic congestion and crowds. 
Noise is one of the major causes of a reduced quality of life, especially in urban environments where its constant presence and influence affect many aspects of everyday life. This is confirmed by the fact that damage to hearing due to noise is among the most prominent problems of professional pathology. If other effects of noise on human organism are added, it is clear what possible consequences noise can have. In today's world, traffic and transport are identified as one of the main noise sources. Accordingly, special attention should be paid to reducing the level of traffic noise; otherwise, there is a danger that the noise level would remain high or even increase. This is corroborated by the fact that the number of vehicles and kilometers traveled per vehicle are constantly increasing from year to year.

Consequently, it is necessary to significantly concentrate on both theory and practice to find ways of combating the harmful effects of traffic noise, i.e. to find measures by which people and their environment can be protected from them and that will allow the smooth progress of their working, social, recreational, creative and other activities.

A large number of health studies and scientific papers deal with the problem of noise impact on the quality of life such as the impact of road traffic noise on sleep and mental health (Belojević et al., 2015), (Bodin, et al, 2015, pp.1612-28), (Sygna, et al., 2014, pp.17-24), (Aasvang, et al., 2011), (Basner, et al, 2008), (Griefahn, et al., 2006), (Kishikawa, et al., 2009), the impact of air traffic noise (Hardoy, et al., 2004), (Schreckenberg, et al., 2010), and the impact of rail traffic noise on the quality of life and health of people (Aasvang, et al., 2008), (Aasvang, et al., 2011). Of course, measures and actions to reduce traffic noise are also research topics in the field of noise impact (Wijnant, Hooghwerff, 2015), (Yamamoto, 2015), (Paffen, et al., 2015), (Ganić, et al., 2015, pp.115-123).

\section{External effects of transport}

Efficient and well-developed transport systems contribute greatly to the smooth functioning of the economy and its development, increasing competitiveness, increasing employment, faster and better exchange of goods and services, as well as increasing mobility of people in order to achieve professional and social activities. An especially important strategic role of transport is reflected in its contribution to the developing of underdeveloped regions and their integration into the global economic mainstream. It is one of the most important factors in achieving the overall economic prosperity of a country and the economic welfare of its citizens. The specificity of the transport sector is also reflected in the fact that the benefits of the investment in the transport infrastructure are 
manifested not only in the transport sector but also in other economic sectors. However, despite the great importance of transport and its enormous contributions to the overall economic welfare, there are significant external effects which, due to their size and possible consequences, generate increasing interest.

In order to understand better the external effects of transport, it is necessary to examine the costs incurred in the transport sector and to make a clear distinction between internal and external costs, Table 1 (Kaplanović, 2012). For the calculation of total costs, in addition to internal ones, external costs should be taken into account. These costs are not borne directly by those who have caused them, but they are borne by other participants in transport (congestion, traffic accidents, etc.) as well as the society in general (environmental costs of pollution, noise, etc.). External transport costs arise when customers do not pay the total cost of transport operations carried out or when they do not receive the full benefit. In other words, external costs are created when the benefit of individuals is affected by the actions of others who do not take into account this influence during their activities (Kaplanović, 2012). This can result in the adoption of wrong decisions on the transport market, and thus in inefficient use of available resources.

Table 1 - Classification of costs in transport

Таблица 1 - Классификация затрат по транспорту

Tabela 1 - Klasifikacija troškova u transportu

\begin{tabular}{|c|c|c|}
\hline \multirow{2}{*}{ The categories of costs } & \multicolumn{2}{|c|}{ Social costs } \\
\hline & Internal costs & External costs \\
\hline $\begin{array}{l}\text { Expenditure on } \\
\text { transport }\end{array}$ & $\begin{array}{l}\text { Costs relating to the vehicle } \\
\text { and the fuel }\end{array}$ & Costs paid by others \\
\hline infrastructure costs & $\begin{array}{l}\text { User fees, taxes related to } \\
\text { vehicle excise duty }\end{array}$ & Uncovered infrastructure costs \\
\hline $\begin{array}{l}\text { Costs of traffic } \\
\text { accidents }\end{array}$ & $\begin{array}{l}\text { Costs covered by insurance, } \\
\text { own costs of traffic accidents }\end{array}$ & $\begin{array}{l}\text { Uncovered costs of traffic } \\
\text { accidents }\end{array}$ \\
\hline Environmental costs & Own loss of benefits & Uncovered environmental costs \\
\hline Cost of congestion & Costs of one's own time & $\begin{array}{c}\text { Delays / time costs imposed on } \\
\text { others }\end{array}$ \\
\hline
\end{tabular}

A large number of negative external effects are connected to transportation, the most important ones being: climate change, air pollution, congestion, traffic accidents, noise pollution, loss of land, generation of waste, vibrations, water pollution, etc. In addition, the 
negative impact is seen in degradation and fragmentation of land, disposal of used transport vehicles and other transport equipment, transport of dangerous goods, endangering the environment, etc. The basic categories of external effects, the types and characteristics of costs and the types of externalities are given in Table 2 (Pejčić, Bojković, 2012).

Table 2 - Overview of the most important external effects of transport

Таблица 2 - Перечень наиболее значимых непредвиденных эффектов транспорта Tabela 2 - Pregled najznačajnijih eksternih efekata transporta

\begin{tabular}{|c|c|c|}
\hline Type of effect & $\begin{array}{l}\text { The most significant cost } \\
\text { components }\end{array}$ & Type of externalities \\
\hline Air pollution & $\begin{array}{l}\text { The damage (cost) for human health } \\
\text { and agricultural goods }\end{array}$ & Completely external \\
\hline Traffic accidents & $\begin{array}{l}\text { Additional costs (medical care, } \\
\text { property damage, human resources) }\end{array}$ & $\begin{array}{l}\text { Partly external (the part } \\
\text { that is not covered by } \\
\text { insurance) }\end{array}$ \\
\hline Climate changes & $\begin{array}{c}\text { Damage (expense) from global } \\
\text { warming }\end{array}$ & Completely external \\
\hline $\begin{array}{l}\text { Congestion on the } \\
\text { roads }\end{array}$ & $\begin{array}{c}\text { Costs for additional time and } \\
\text { exploitation }\end{array}$ & $\begin{array}{l}\text { External for individual } \\
\text { users, and internal } \\
\text { distribution by sectors }\end{array}$ \\
\hline $\begin{array}{l}\text { Processes "up-and } \\
\text { downstream" }\end{array}$ & $\begin{array}{l}\text { Additional environmental costs (air } \\
\text { pollution, climate change) }\end{array}$ & Completely external \\
\hline Noise & $\begin{array}{c}\text { The damage (cost) for human health } \\
\text { and the reduction of the value of a } \\
\text { potential residential exposed to } \\
\text { noise }\end{array}$ & Completely external \\
\hline $\begin{array}{l}\text { Additional costs in } \\
\text { urban areas }\end{array}$ & $\begin{array}{c}\text { Costs in the form of additional time } \\
\text { for separation and / or lack of space } \\
\text { for non-motorized modes of } \\
\text { transport }\end{array}$ & Completely external \\
\hline $\begin{array}{l}\text { Soil degradation } \\
\text { due to construction } \\
\text { of transport } \\
\text { infrastructure }\end{array}$ & $\begin{array}{l}\text { Additional costs of repairing the } \\
\text { damage, the costs of compensation }\end{array}$ & Completely external \\
\hline
\end{tabular}

The costs of energy dependence, aesthetic consequences, waste generation, water pollution, vibration, land use, separation etc., are also external effects of traffic and transportation to which, however, less attention is now devoted. 


\section{Traffic noise}

\section{The impact of noise}

The sense of hearing has a big impact on the overall condition of the human organism, in a physiological as well as psychological domain. It connects people with the environment and allows them to communicate with other people. In addition, hearing is the most sensitive and most important mechanism for warning against danger, because at any time humans receive impressions from the surroundings, regardless of whether they are awake or asleep. Noise is one of the leading problems in urban areas, because exceeding the permissible noise levels can significantly affect the quality of life. Noise can affect human health in many ways, causing nervousness, sleep disturbances, and disruptions in communication, reducing working capacity, leading to the consequences in social behavior, as well as to the loss of hearing. Also, noise can result in a disruption of daily activities, thus causing general discomfort, stress and frustration. Due to increased exposure to noise, physical, mental and emotional health may be disturbed. People exposed to high levels of noise, compared to those less exposed, have an increased number of headache occurrences, higher sensitivity to small incidents, increased dependence on sedatives and sleeping pills, increased level of mental illness, etc. Exposure to noise is also associated with a number of possible physical effects such as colds, changes in blood pressure and other cardiovascular changes, problems with the digestive system, as well as chronic fatigue, while prolonged exposure to noise levels of $80 \mathrm{~dB}$ or more can cause deafness (Zatežić, et al., 2009). According to the World Health Organization, it is estimated that 1.3 billion people worldwide have hearing damage due to noise impact, while $10 \%$ of the world population is currently exposed to noise levels that can cause hearing damage (European Commission, 2015).

Intensive urbanization and industrialization in the modern world has contributed that noise becomes one of the most damaging environmental factors. At the beginning of this millennium, $50 \%$ of the planet's population is living in cities, and it is anticipated that this number will increase in 2025 to $75 \%$. In 1960, there were only two cities in the world with over 10 million inhabitants, while in 2025 there is a prediction for 28 mega cities (Zatežić, et al., 2009). There is a trend of noise level increase in the underdeveloped part of the world and in developing countries where extremely high noise levels between 90-100 dB occur as a result of the dominant use of outdated engines, diesel vehicles and motorcycles. It is generally accepted that a noise level of $55 \mathrm{~dB}$ is considered disturbing, while a noise level of $65 \mathrm{~dB}$ is considered 
intolerable. In accordance with this classification, it is estimated that $30 \%$ of the EU population live in conditions of unacceptable noise levels, while about 170 million people live in so-called 'gray areas' with high noise levels during the day (Radosavljević, Vukadinović, 2014, pp.925-930).

Also, cardiovascular diseases such as high blood pressure, heart disease and stroke are associated with long-term exposure to noise. This is corroborated by the results of the published studies showing that an increase in traffic noise levels of $10 \mathrm{~dB}$ may increase the risk of high blood pressure or heart disease from 7 to 17\% (European Commission, 2015). Exposure to noise from road, rail and air transport over a longer period may also affect children's learning and development. A study conducted in 89 schools in the vicinity of major airports in London, Amsterdam and Madrid, for children aged 9 to 10 , showed that the traffic noise adversely affects the ability of learning as well as memory (European Commission, 2015).

In Europe, in recent years, more attention has been paid to the problem of external costs of noise. Costs of exposure to noise are mainly related to the decrease in house prices, reduced possibilities of land use, increased medical costs, costs of lost productivity in the workplace, etc. In Switzerland, for example, the external costs of transport due to noise have been estimated to around 1.5 billion euros, of which $81 \%$ are attributable to road traffic, $15 \%$ to rail and $4 \%$ to air traffic (European Environment Agency, 2014). In Sweden, social annual costs caused by road traffic noise are estimated at over a billion Swedish krona, 908 million are the estimated costs due to rail traffic and 62 million krona due to air traffic (European Environment Agency, 2014).

In the modern world, transport has been identified as the main source of noise pollution. Of all modes of transport, road transport, with a share of about $65 \%$ in the total traffic noise pollution from transport (Vukasinovic, 2013), appears as a major polluter. It is estimated that in the EU about 125 million people are exposed to road traffic noise exceeding $55 \mathrm{~dB}$ (European Environment Agency, 2014). The main noise sources of this form of transport are noise from engines, noise generated from the friction of wheels over the road surface and the noise from exhaust systems (Figure 1). When observing road traffic, one of the most important factors that affect noise intensity is the speed of vehicles. At low speeds, the impact of the vehicle structure is more important for the level of noise than the interaction of vehicles and the road surface. At speeds above $30 \mathrm{kph}$ for passenger cars and $40 \mathrm{kph}$ for trucks, the impact of tires on the road surface becomes significant, while at speeds over $50 \mathrm{kph}$ this influence becomes dominant (European Commission Working Group 5, 2002). From the above, it can certainly be concluded that the noise level increases with vehicle speed increase. For example, a car moving at $20 \mathrm{kph}$ emits $55 \mathrm{~dB}$ of noise, one that is moving at 40 kph generates $65 \mathrm{~dB}$, a speed of $80 \mathrm{kph}$ generates noise of $75 \mathrm{~dB}$, while 
a speed of $100 \mathrm{kph}$ generates up to $80 \mathrm{~dB}$ (Figure 2). Some studies have shown that in urban areas, where speeds are from 30 to $50 \mathrm{kph}$, the noise from the operation of vehicle engines plays an important role, while on the highway, the above mentioned noise source can be ignored.

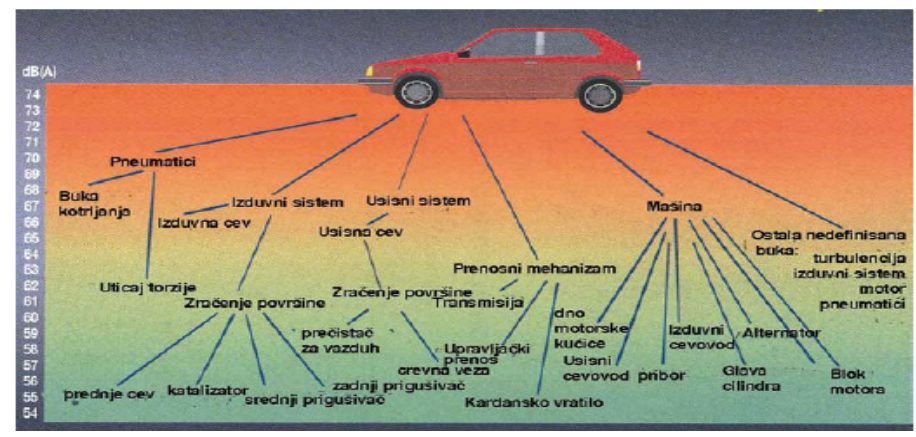

Figure 1 - Generation of noise by car

Puc. 1 - Генерирование дорожно-транспортного шума Slika 1 - Generisanje buke koju emituje automobil

The intensity of the traffic noise of road vehicles depends on the "content" of traffic. So, for example, a truck at a speed of $90 \mathrm{kph}$ emits noise intensity equal to 28 passenger cars which move at a speed of 90 kph (Bogojević, et al., 2011).

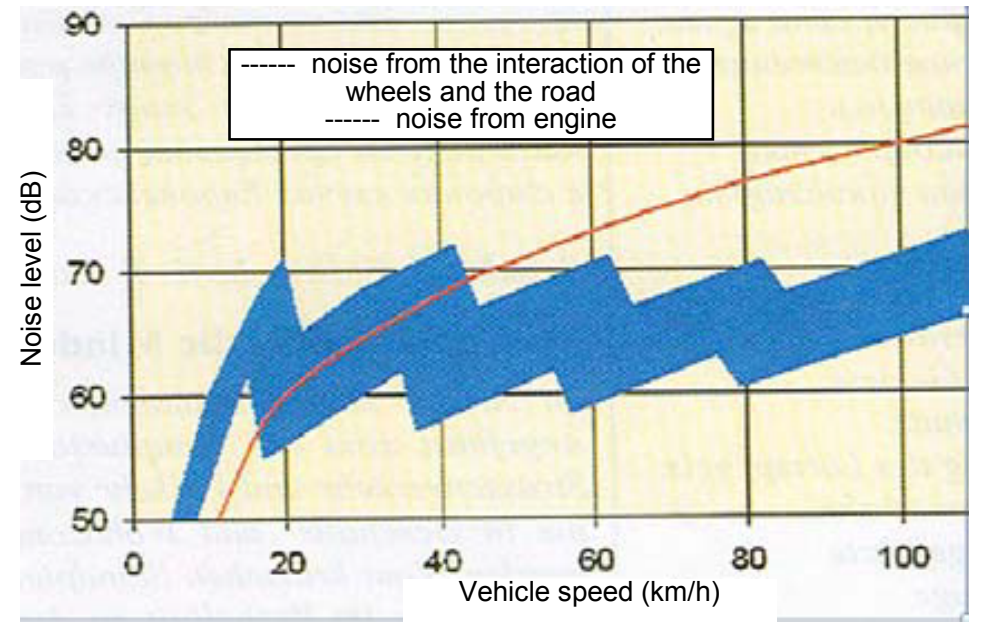

Figure 2 - The dependence of the noise level due to the interaction of tires and the road surface and due to vehicle engines

Puc. 2 - Зависимость уровня шума от контакта покрышек

и поверхности дорожного покрытия, а также от работы двигателя

Slika 2 - Zavisnost nivoa buke od interakcije pneumatika i površine kolovoza i od rada motora vozila 
The second largest source of noise emissions in transport is air transport in the total noise pollution from transport and it accounts for about 20\% (Vukašinović, 2013). The problem of traffic noise in air transport has come to a focus due to the forecast that the volume of traffic in Europe by 2020 will increase by 3 times compared to 2000 . Operations of landing and takeoff of aircraft (airplanes and helicopters) generate significant levels of noise near commercial and military airports. Noise caused by the operations of landing and take-off is directly dependent on the number of aircraft, landing and takeoff corridors and atmospheric conditions. Also, noise sources are aircraft propulsion systems and aerodynamic noise. Aerodynamic noise is dominant only in the phase of flight, whereas in the phase of landing and takeoff a dominant noise source is the propulsion system.

Rail transport accounts for about $15 \%$ of the total emissions in traffic noise (Vukašinović, 2013). The origin of this type of noise is linked to locomotives (mainly those that use diesel engines), friction between wheels and rails, locomotives and wagon braking, horns, crossing the railway crossings, aerodynamic noise produced when trains move at high speeds, and others. (Bogojević, et al., 2011). The noise emitted by locomotives mainly occurs during work of traction motors, engine cooling systems, gear systems and ventilation systems. The interaction of wheels and rails is a dominant noise source and directly depends on the speed and the geometric configuration of tracks. On straight track sections, noise is mainly generated as a result of surface roughness of wheels and rails, and their mutual friction, while at overcoming curves, wheels create more noise due to the sliding of metal wheels on rails. The cause for this phenomenon is of the constructive nature of wagons where wheels are fixed in parallel axes, thus taking the outer wheels more time to pass curves than the inner ones.

The noise generated by the braking process, in addition to the roughness of contact surfaces of wheels and rails, significantly depends on the type and kind of brakes used. So, for example, when braking with wheel slippers brakes with inserts made of cast iron, the noise level is 10 $\mathrm{dB}$ higher than in the case of disc brakes with discs mounted on wheels. In the case of wheels with slippers brakes with inserts of composite materials, the noise level is less than half the level of that of wheels with slippers brakes with inserts made of cast iron and disc brakes. The majority of fans and their motors generate noise. It is important to mention noise generated by sound signal alerts and notifications as well as aerodynamic noise caused by train running. The noise level generated by air turbulence is proportional to the speed of the train. Aerodynamic noise is significant only at higher speeds. Additional sources of noise in relation to rail transport are linked to the operations of loading, unloading and reloading. 
The overview of the noise levels by types of specific means of transport is shown in Table 3, where it can be seen that combat aircraft and military vehicles emit the most noise (Zatežić, et al., 2009), (Živković, et al., 2000, pp.566-576).

Table 3 - Noise levels of means of transport

Таблица 3 - Уровень шума дорожно-транспортных средств

Tabela 3 - Nivo buke prevoznih sredstava

\begin{tabular}{||l||l||}
\hline \hline The means of transport & Exterior noise levels $(\mathrm{dB})$ \\
\hline \hline Bus & $72-75$ \\
\hline Passenger car at a speed of $90 \mathrm{kph}$ & $82-87$ \\
\hline wagon train & $85-88$ \\
\hline underground railway & $98-103$ \\
\hline truck & $82-89$ \\
\hline plane (passenger) & $97-113$ \\
\hline helicopter & $89-110$ \\
\hline a column of tanks & $88-96$ \\
\hline
\end{tabular}

To estimate the costs caused by noise, it is necessary to solve first the problem of noise measuring, which arises from the same noise complexity as the external noise effects. In fact, one of the main characteristics of noise is reflected in its multiple behavior and the fact that noise changes in time and space. The difficulties in measuring noise are associated with the fact that the noise level depends on the characteristics of transport (vehicle types, traffic intensity, the behavior of drivers, etc.), on types, conditions and quality of roads and also on the characteristics of the environment. In the longer term, wind, weather and seasons also affect noise levels. This means that it cannot be determined with certainty what the noise level will be at a particular place at a particular time. However, if noise sources are defined appropriately, then it is possible with a certain degree of confidence to determine what the average noise level will be in the long term.

\section{Reducing the impact of traffic noise}

From the aspect of traffic external effects, transport policy is important as a whole, as a set of measures to guide the development and operation of traffic in desired frames. Specific measures which are of major importance in terms of ecology, in the case of traffic, refer to the standards to be observed by manufacturers of vehicles and parts, as well as those who invest or exploit transport infrastructure (rail, road infrastructure, airports, ports, etc.). In addition to technical innovations in engines, the application of quality energy sources, stringent emission controls, and stricter air quality standards, it is necessary to take measures to restrict car use and increase the use of mass transport of passengers (Službeni glasnik RS, 4/2008). As 
traffic volume and noise levels are closely linked, a further rise in the volume of traffic in cities can only continue to increase the level of noise. Reducing the use of private cars and increasing the use of public transport and the use of bicycles are some of the solutions to reduce the volume of traffic in residential areas, and therefore the noise it creates.

Activities to be implemented throughout Europe in order to reduce noise in the environment have a different priority compared to the environmental problems, often because it was thought that such issues are best handled at national or local levels. In the initial stages of the European Union, the regulation on noise management was based on the objectives of internal markets. As the information on the impact of noise on human health is increasingly becoming available, the need for a higher level of protection for citizens through a wider frame in the whole Europe is becoming more distinct. A milestone in the European strategy to combat noise was the adoption of the document "Green Paper" in 1996, which represents a new strategy to combat noise. Its vision for the year 2020 shows that no person should be exposed to noise levels which endanger health and quality of life, and that is necessary to avoid harmful effects of noise originating from all sources and to preserve quiet zones. The document "Green Paper" proposed a new framework for understanding the impact of noise and created opportunities for progress in three key areas: noise,

- Raising the level of awareness about the impact of environmental

- Better and more detailed public information and involvement of the public in solving the problem of noise, and

- Reducing noise levels as a part of an integrated strategy for better life on the Earth.

Also, the "Green paper" has defined the target values of noise reduction for four basic types of noise sources as well as the basic guidelines for achieving the set goals:

a) Reduction of road traffic noise emissions to $10 \mathrm{~dB}$ :

- noise reduction that occurs in the interaction of tires and the road surface in cooperation with constructors of tires and road linings,

- reduction of engine noise (machines, transmissions and exhaust systems) by using new materials and active systems to control noise and vibration,

- traffic management using modern systems which enable functioning of traffic without congestion and delays, and

- improving regulations.

b) The reduction of noise emissions of rail transport up to $20 \mathrm{~dB}$ for freight traffic and up to $5 d B$ for fast tracks:

- reduction of noise generated by the interaction of wheels and rails using new materials for rails and wheels and new technology to connect rails,

- reduction of aerodynamic noise of trains for high-speed railways, and

- reduction of noise generated during braking and overcoming curves. 
c) reduction of emissions of air traffic noise up to $10 \mathrm{~dB}$ per operation during landings or takeoffs:

- noise reduction at aircraft using new aircraft constructions with improved dynamics and active noise control measures, and

- optimization of landing and takeoff operations. 10dB:

d) The reduction of noise emissions of equipment used outdoors to

- identification of the parameters of certain categories of equipment that affect the generation of noise,

- correlation of noise emissions and the identified parameters, and

- monitoring the effects of individual and combined effects of noise sources on its perception.

On $25^{\text {th }}$ June 2002, the European Parliament and the Council adopted Directive 2002/49/EC on the assessment and management of environmental noise, which is known as the "END". The Directive aims to define a general approach to avoid, prevent or reduce harmful effects stemming from exposure to noise and noise in the environment. In addition, the Directive aims at establishing a basis for developing EU measures to reduce noise emitted by the major sources, in particular road and rail vehicles and infrastructure, aircraft, external and industrial equipment and mobile machinery (Official Journal of the European Communities, 2002).

The activities regulated by Directive 2002/49/EC are:

- Monitoring the environmental problem: the competent authorities are obliged to draw up "strategic noise maps" for major roads, railways, airports and densely populated agglomerations.

- Informing and advising the public about noise exposure, its effects, and measures against noise.

- Addressing local issues related to noise by requiring the competent authorities to draw up action plans to reduce noise in problematic areas, as well as by maintaining the level of noise in the environment where it is at a satisfactory level.

- Developing a long-term strategy of the European Union, which includes targets for reducing the number of people vulnerable to longerterm noise levels and creating a framework for the development of existing policies on the reduction of noise at source. traffic:

There are four basic groups of measures to reduce noise levels from

- noise reduction at source,

- reducing the propagation of noise,

- noise protection at the place of immission, and

- economic measures and regulations. 
The first group is a primary measure, while the other three are secondary measures of protection against noise. The paper will set out the measures considered for road and rail and trams.

\section{Noise reduction at source}

\section{Road traffic}

In road traffic, high noise levels arise as a result of the vehicle structure and the interaction between the vehicle and the road surface, so when talking about reducing noise at source, it is necessary to act on all these components. The operations relating to the improvement of the vehicle structure include a series of measures related to the reduction of noise originating from engines, transmission mechanisms of vehicles, tires and the like. In 1970, Directive 70/157/EEC was adopted about prescribed permissible motor vehicle (cars, trucks and buses) noise levels, and it has undergone several amendments until today. Vehicle production must meet the requirements prescribed in that Directive. Attention is increasingly focused on the possibility of reducing noise from the interaction between tires and the road surface, which can be achieved by:

- reducing the speed of vehicles,

- selection of a particular type of road track surfaces,

- maintenance of roads and vehicles,

- traffic management, and

- behavior of drivers and the introduction of restrictions.

Reducing speed. The noise level can be reduced by limiting the permitted speed of vehicles. This measure does not affect only the reduction of the noise level, but also affects the increase of security of traffic participants. Double reduction in vehicle speed can result in noise reduction from 6 to $8 \mathrm{~dB}$ (Figure 3).

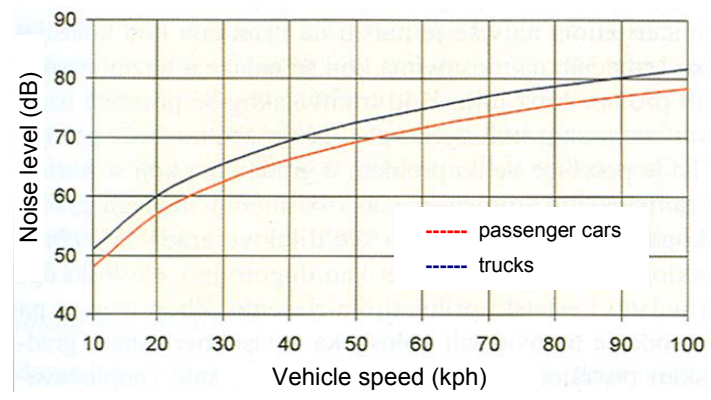

Figure 3 - Influence of vehicle speed on noise levels

Puc. 3 - Влияние скорости автомобиля на уровень шума Slika 3 - Uticaj brzine vozila na nivo buke 
Road surface. The road surface with an open and porous texture is not suitable only for noise reduction, it also provides a better tire grip and, consequently, better driving safety. Such a road surface reduces noise levels from 2 to $4 \mathrm{~dB}$. The disadvantage of this solution lies in the need for intensive maintenance; in addition, considerable damage occurs during winter as a result of freezing.

Maintenance of roads and vehicles. Good maintenance reduces the dynamic effects of vehicles and load on the road, and affects the reduction of noise levels as well. Poor maintenance of roads greatly influences the increase of traffic noise, especially from the interaction of tires and the road surface (Lakušić, et al., 2005, pp.1-9).

Traffic management. Traffic management means the operation of reducing the traffic load by redirecting a part of the overall traffic or a certain type of vehicles to other roads, limiting the time in which it can operate (the ban on traffic of heavy vehicles during weekends and at night), and ensuring a status of free traffic flow (shutting down traffic lights). Free flow of traffic leads to noise reduction of up to $4 \mathrm{~dB}$, while shutting down traffic lights can have a twofold effect - it cannot be better as it creates a possibility of increasing the speed of traffic, and the reduction of the noise level in this way is rarely higher than $2 \mathrm{~dB}$. The effect of reducing the traffic load on the noise level is shown in Figure 4.

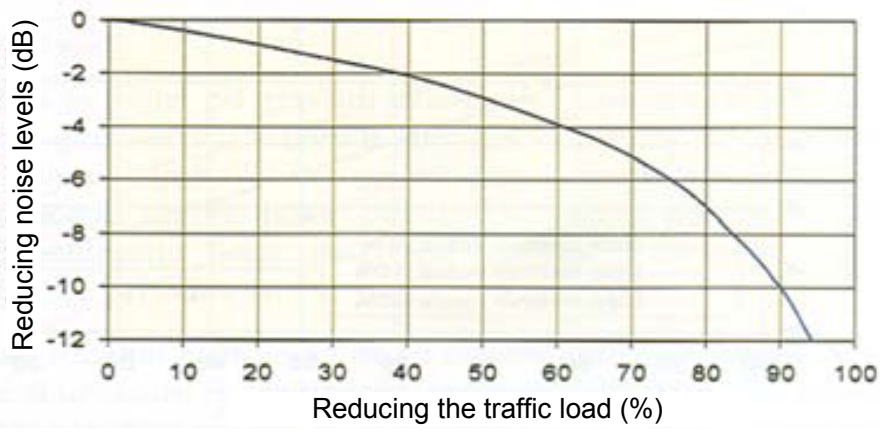

Figure 4 - Effect of reducing the traffic load on the noise level

Puc. 4 - Влияние снижения дорожно-транспортного движения на уровень шума Slika 4 - Uticaj smanjenja saobraćajnog opterećenja na nivo buke

When speaking of diverting traffic, it should be noted that the removal of traffic from one road causes an increase in the noise level on other roads. This measure is somewhat justified if the traffic from smaller urban traffic is diverted to bypass roads or to those intended for intense traffic, which can result in a smaller increase in the noise level on the road to which traffic was diverted. For city roads, the mentioned measures can be significant. 
Driver behavior and the introduction of certain restrictions. The noise level of an individual vehicle depends not only on its speed, but also on the degree of transmission and the methods of acceleration and deceleration. Passive driving can lead to reducing noise by approximately $5 \mathrm{~dB}$ for passenger and commercial vehicles, and by $7 \mathrm{~dB}$ for motorcycles (European Commission Working Group 5, 2002). Motorcycles are a particular problem because of a potential increase in noise up to $20 \mathrm{~dB}$, and for this reason, driving bans can be introduced on certain roads at night or driving without a special built-in silencer can be prohibited.

One way of overcoming the problem of noise that occurs as a result of vehicle engines is the use of low-noise vehicles, such as hybrid vehicles, electric ones, etc. Hybrid vehicles are vehicles with low emission (LEV - Low Emission Vehicles), driven by two sources of energy: the energy conversion aggregate (combustion engine or fuel cell) and the aggregate for the accumulation of produced energy (Banković, 2010). Unlike hybrid vehicles, electric vehicles use exclusively electric motors as the main and only engines. The biggest car manufacturers are working intensively on the development of vehicles with hydrogen fuel cells. Hydrogen drive is particularly suitable for use in public transport vehicles. One of the advantages of fuel cell vehicles is that they are tanked much faster and that can cover more kilometers without refueling than electrically powered vehicles (Banković, 2010). Although beneficial, a silent operation of these vehicles can affect the safety of participants in traffic. Hybrid, electric and vehicles using hydrogen are particularly silent, to the point that they are silent even for pedestrians, which may affect their safety.

Railway and trams

The movement of railway vehicles, trains and trams, is also a significant source of noise. Today, rail transport is becoming increasingly important because freight traffic is trying to shift from road traffic to railways (European Commission, 2011). This leads to an increase in the volume of rail transport and the use of trains of considerable length. Without the application of protective measures, especially in those places where the railroad passes through populated areas, there would be a significant increase in noise levels. "European Commission Green Paper" of 1996 criticised rail transport for its contribution to the increase in noise levels and stressed that noise reduction is a prerequisite for its greater exploitation (European Commission, 1996). Reducing noise due to rail traffic can be accomplished by:

- selection of a type of construction of rail track superstructures,

- maintenance of the running surface of rails and wheels of vehicles,

- selection of a type of vehicles (wagons), and

- reducing the speed of trains and trams. 
Type of construction of permanent tracks. The construction type of tram and railway superstructures plays a very important role in reducing noise emissions, especially types of rail mounting on the ground and a method of closing (covering) tracks. The choice of sleepers also affects the noise level. Research conducted in Germany has shown that the level of noise due to a train running on the track with wooden sleepers is up to $2 \mathrm{~dB}$ lower than in the case of the track with concrete sleepers. In addition to the system of fixing rails to their support, a method of closing (covering) the permanent track also has a very important role in reducing noise propagation. Closing a classical successive track structure with corresponding absorbent materials is mostly used for tracks on bridges located near settlements or passing through them. In tram transport, considerably more attention is devoted to a mode of closing tracks. This is a particularly big problem in cities that use tram transport as the main type of urban public transport. Therefore, setting up and closing tram tracks in urban areas create a major requirement in order to obtain the best possible construction of tram tracks which, in addition to aesthetic requirements, meet the requirement of reducing noise emissions.

The rail running surface. In Brussels in 2003, a working group of the European Commission dealing with noise from rail traffic formulated a strategy and priorities for reducing noise from rail transport. The greatest attention is given to noise due to the interaction of wheels and rails. The various geometrical irregularities both on wheels (flat points, irregularities in wheel shapes, mechanical damage) and rail running surfaces (wear, composition of rails, errors on welds) significantly affect the increase in noise levels. The Commission has adopted a strategy called 'smooth wheels on flat rails', in order to take stricter measures of control and maintenance of vehicle wheels and the running surface of rails. Of course, the development of modern and contemporary electromagnetic trains is one of the ways to reduce the noise impact of rail transport, since it allows movement of trains without wheels. They float on magnetic cushions without contact with the support; namely, they do not need wheels or cylinders, which means no friction and therefore no noise that occurs due to the interaction between wheels and rails. At a speed of around $200 \mathrm{kph}$, an electromagnetic hovering train is barely heard because its contactless technology does not produce neither noise nor the rolling noise of the engine. At higher speeds, the sound of aerodynamic wind can only be noticed; at a speed of $300 \mathrm{~km} / \mathrm{h}$ electromagnetic trains are still quieter compared to a car moving at a speed of $70 \mathrm{kph}$ and compared with a truck at a speed of $45 \mathrm{kph}$. However, one of the biggest disadvantages of this system is the high cost of construction. It is cost-effective only at railroad sections where large quantities of passengers and goods are transported. 
Type of vehicles (wagons). A very important role in noise abatement is played not only by the type of construction of the tram track upper surface, but olso by the type of rail vehicles (wagons). Research conducted in the past has shown that different types of rail vehicles (tram, passenger or freight trains) have different effects on noise level increase. The construction of tram vehicles, stiffness and suspension characteristics of tram vehicle wheels in particular, contribute to reducing the level of noise emitted.

Reducing speed. Lower speed of rail vehicles contributes to the reduction of noise levels. At high speeds, a dominant noise source is the interaction of wheels and rails. At low speeds, noise levels are 3-7 dB lower than in the case of the train operating speed. Also, measurements of noise levels in urban areas have shown that at low speeds the tram noise level is lower by up to $10 \mathrm{~dB}$.

\section{Reducing noise propagation}

As the reduction of noise levels at the source cannot often result in the prescribed permissible level of noise, noise reduction measures are applied involving the use of different barriers for protection against noise and planned utilization of space in the vicinity of motorways. It is known that roads and tram and railway roads generate high levels of noise in their environment. When the construction of new or reconstruction of existing roads is planned in populated areas, a special attention must be paid to the protection of existing facilities. In such cases, it is necessary to distinguish two situations: when the area near the road is less populated and when it is a densely built-up area. Proper planning of roads through sparsely populated areas can eliminate adverse effects of increased levels of traffic noise. In densely built-up areas, a careful attention must be paid to the protection of existing facilities. This includes urban planning of urban areas and roads in relation to buildings, planning and defining permissible noise levels for each zone, which can be regulated within the urban plans for settlements (Službeni glasnik RS, 88/2010).

In the process of planning and space management, in order to reduce noise propagation, it is possible to take the following measures:

- provide sufficient distance between residential areas and noise sources, and

- locate objects that are not affected significantly by noise (parking lots, shopping centers, etc.) in areas between noise sources and residential areas sensitive to high levels of noise.

The existing structures such as buildings, fences, billboards, tree lines, embankments, etc., located next to roads, are also a kind of barrier protection against noise even though it is not their primary function (Figure 5). In this way, in some cases noise levels can be reduced up to 12 dB (Lakušić, et al., 2005, pp.1-9). 


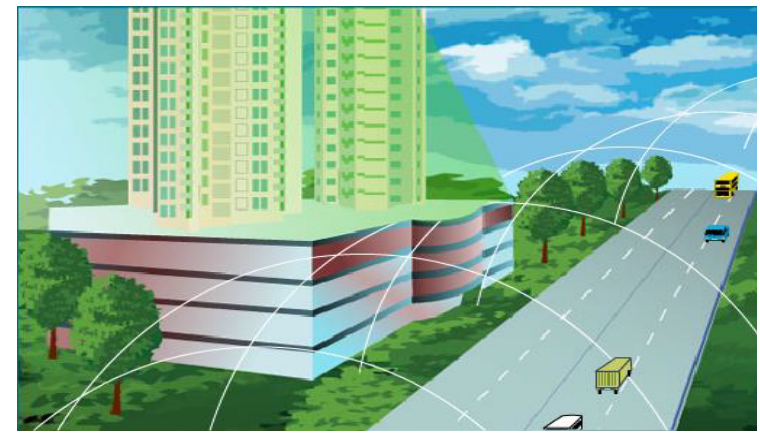

Figure 5- Reducing traffic noise with objects

Puc. 5 - Снижение дорожно-транспортного шума с помощью объектов Slika 5 - Smanjenje saobraćajne buke pomoću objekata

Setting up barriers for noise protection right next to routes (roads or railways) is one of the most common and safest ways to reduce noise propagation (Figure 6). For instance, Dutch national legislation in 1979 started solving this problem at a level a lot stricter than the regulations of the time. The result was the fact that in 2001 there were approximately $450 \mathrm{~km}$ of barriers for protection against noise positioned next to the national roads in the Netherlands, with the existing development plans to build additional $20 \mathrm{~km}$ every year. Barriers of sufficient height and sufficient length lead to the effect of reducing noise levels from 7 to $12 \mathrm{~dB}$ (European Commission, 2015). These technologies are not only economical, but can also be implemented in a relatively short period of time. Barriers for protection against noise fulfill their purpose by interrupting or blocking the direct path between the noise source and the receiver. Also, barriers may reflect noise, thus increasing noise for people living on the opposite side of the road. Therefore, a barrier against noise must have absorption characteristics.

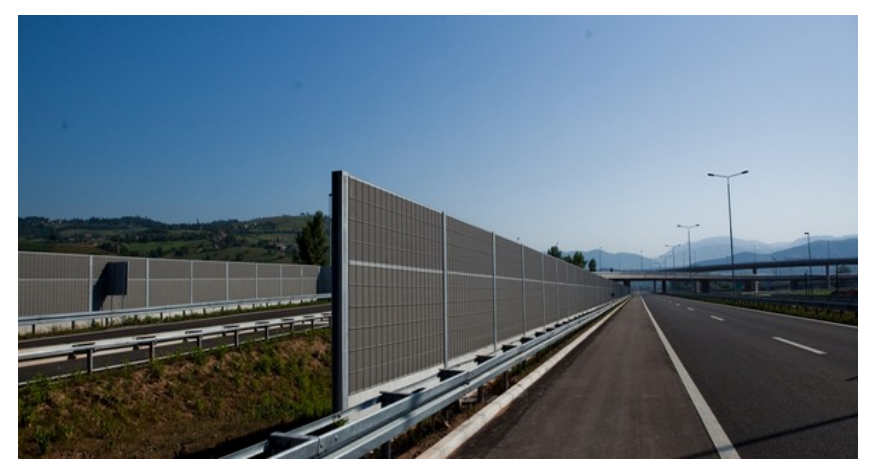

Figure 6 - Barriers for protection against noise

Puc. 6- Шумозащитный барьер Slika 6 - Barijera za zaštitu od buke 
Placing roads in recesses or constructing tunnels (when there is a need for a high degree of reduction of noise levels), are also methods of reducing traffic noise (Figure 7). Tunnels are built in urban areas where the price of land is very high and they are the most effective way of protection against noise. At the entrance, tunnel walls are usually lined with absorbent panels to reduce the propagation of noise in the environment. Wall cladding with panels is also widely used at the entrances and exits of underpasses which are more commonly used in urban areas. Namely, lining walls with absorbing panels can reduce noise levels by up to $10 \mathrm{~dB}$ (European Commission Working Group 5, 2002). However, this measure has its drawbacks which relate primarily to high construction costs as well as to significant costs of tunnel maintenance.

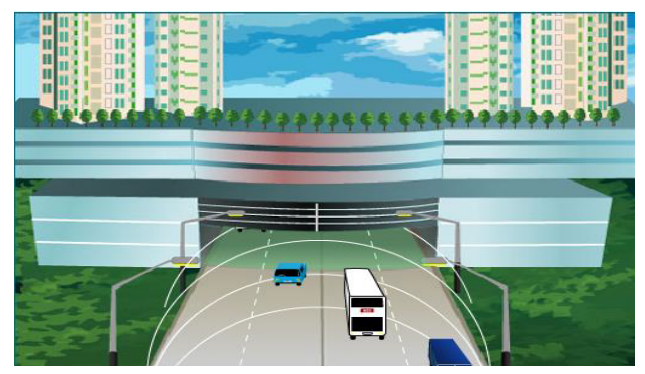

Figure 7 - Tunnels in the function of protection against traffic noise Puc. 7 - Тоннели в качестве защиты от шума Slika 7 - Tuneli u funkciji zaštite od saobraćajne buke

\section{Protection against noise at the site of immission}

If there is no possibility to reeduce noise at source or prevent its propagation, noise protection measures at the site of immission can be applied, reducing noise levels from 6 to $16 \mathrm{~dB}$ (Radosavljević, Vukadinović, 2014, pp.925-930). This method of noise protection involves the use of sound insulation, as well as greater attention to the design of buildings. When using acoustic insulation, the best effects are obtained by insulating walls, windows and doors. The use of sound insulation as well as noise protection is mainly considered as a last option because of the high cost. For example, the price of additional sound protection of a residential building is about $15 \%$ of the price of the object itself when the external noise level is 75-77 dB (European Commission Working Group 5, 2002). More and more attention is paid to the design of buildings. With objects placed along roads, the biggest problem with high levels of noise occurs in premises directly facing roads. To reduce the price of sound insulation in such a facility, at the design stage less sensitive areas (kitchen, bathroom, storage) can be oriented towards the road, so that the remaining parts (bedrooms, living rooms and study rooms) are on the 'quieter' side of the building. 


\section{Economic measures and regulations}

Economic measures for the protection of the impact of traffic noise include fees for vehicles with noise levels higher than prescribed, incentives that support the reduction of noise level, fuel prices, establishing funds whose assets are intended for the implementation of measures for noise protection, research and development. Some of possible economic measures are:

- Incentives - for each $\mathrm{dB}$ below the permitted limit value, the manufacturer is provided a certain amount of money in the form of incentives, so that manufacturers can introduce their products to market at more competitive prices thus attracting more customers.

- Taxes - for each $\mathrm{dB}$ above the permitted threshold value, a vehicle owner pays a fee.

- Establishment of funds where money is collected by taxes, which can later be used for the implementation of measures for protection against noise or research and development of new technologies.

- Fuel prices can encourage customers to use quieter fuels (diesel engines produce more noise than gasoline ones), vehicles that consume less fuel (generally newer, better maintained and quieter vehicles), or to change their driving style (aggressive driving means that the engine rotates faster, which results in higher fuel consumption and increased noise levels).

However, even in developed countries, economic measures are not widely applied, although they represent an easier method of reducing noise levels. The reason for this can be found in the fact that such measures are difficult to control.

\section{Situation in the Republic of Serbia}

The issue of external effects of traffic and transport in the Republic of Serbia is extremely complex because of the country's unstable economic conditions, lack of funds, regulatory mechanisms, ecological culture and ethics. Despite the complexity of the problem, there are more reasons to pay attention to resolving these problems (Public Enterprise Roads of Serbiaa, 2012). Since external costs are difficult to define, quantify and charge through certain economic mechanisms, our theory and practice use European experiences which show that economic, environmental and transport policies are integrated to solve the problem of external costs of transport.

In the Republic of Serbia, traffic and transport are also the most prominent source of noise in the environment. More than $60 \%$ of the urban population in Serbia are exposed to traffic noise levels that are considered to seriously jeopardize the quality of life. Approximately $25 \%$ 
of the population are exposed to such noise levels that have already caused health problems, which was confirmed by the Institute for Hygiene and Medical Ecology, Belgrade (izveštaj o realizaciji G2G projekta za Srbiju, 2011). Unlike in developed countries, in our country the concern about the problem of noise is still under-represented, often omitted. Health problems, whether they are of objective or subjective nature, reduced ability to work or even disability, are quite a sufficient reason for noise to be treated as an alarming problem of environmental pollution. Unfortunately, we must point out that in our country this danger is still not understood with sufficient seriousness, and is sometimes completely ignored. This is supported by the fact that, according to the report of the Agency for Environmental Protection, in 2012, out of the total investment in environmental protection, the percentage of funds allocated for programs of protection against noise was 0\% (Agencija za zaštitu životne sredine, 2014). Measurements of noise levels have been carried out in Belgrade from 1970s (Gradski zavod za zaštitu zdravlja Beograd, 2002), (Izveštaj o realizaciji G2G projekta za Srbiju, 2011). Noise measurements in 2012 in Belgrade showed that the measured noise levels were higher than allowed during the day at 25 measuring points, while during the night higher levels occurred at 34 measuring points (Gradski zavod za javno zdravlje, 2013). Due to possible increase in traffic caused by the development and possible growth of economic activities, these numbers are expected to increase in the near future.

In 2013, the Institute of Public Health of Voivodina presented the Report on the assessment of the noise impact on the health of the population of Novi Sad within which citizens over 65 years of age were surveyed. Among other things, the report has shown that the most annoying is noise originating from transport $(47 \%)$. Out of the total number of citizens surveyed, $46 \%$ would change a flat because of traffic noise, and $6 \%$ of them had already submitted a complaint to the authorities because of traffic noise. Also, more than a half of interviewed citizens (51\%) said that they were awakened by traffic noise at night (Institut za javno zdravlje Vojvodine, 2013). The Institute for Material Testing, Belgrade, carried out noise measurements in the same city at seven locations in the period from June 2014 to May 2015. The analysis results showed numerous deviations of the measured noise levels from the presribed limits. This led to the conclusion that all measuring locations were critical, given that, in relation to the noise limit values, the deviations of the measured noise levels at all measuring points for the night were greater than $3 \mathrm{~dB}$, while three measuring points were very critical given that their measured noise levels for day, evening and night were constantly higher than $10 \mathrm{~dB}$ (Institut za ispitivanje materijala a.d. 2015). Also, a 2014 study states that the levels of traffic noise for the city of Novi Sad in most cases are higher than 1 to $8 \mathrm{~dB}$ during the day, and from 1 to $9 \mathrm{~dB}$ during the night. Particularly worrying is the fact that the noise levels 
in school zones exceed the permissible noise levels for 12 to $16 \mathrm{~dB}$, while in residential areas noise is higher from 9 to $16 \mathrm{~dB}$ during the day and from 11 to $18 \mathrm{~dB}$ during the night (Djercan, et al., 2014, pp.977-986).

According to the European Committee for Environment and Health, in Serbia there are difficulties associated with inadequate legislation and limit noise values, inadequate monitoring of noise in urban areas, lack of activity of noise zoning in the process of spatial planning, unfavorable locations of industrial areas, lack of projects for the protection of noise, insufficient monitoring of noise emitted by motor vehicles, as well as with inadequate traffic management (Izveštaj o realizaciji G2G projekta za Srbiju, 2011). There was also a lack of adequate knowledge about the development and application of low-noise road surfaces, which is why technology and knowledge related to the construction of this type of roads should be developed. The EU and worldwide experience should be used and modified to suit local conditions. Such an approach would create conditions for Serbia to apply low-noise road surfaces and barriers for protection against noise. In this way, the negative aspects of the impact of infrastructure development on the environment will be significantly reduced, and the noise levels will remain below the levels acceptable by the European Union standards and standards for environmental protection of the Republic of Serbia.

\section{The situation in the Serbian Armed Forces}

Military transport, as a part of the transport system of the country, also causes negative external effects of traffic and transportation. The noise of military vehicles is the result of a large number of devices and systems, each of which produces noise of more or less high intensity. The most significant sources of noise are: exhaust and intake systems, combustion noise and mechanical engine noise of military vehicles, cooling systems and tires, power systems and aerodynamic noise of military aircraft, moving of combat vehicles and others. Measures to reduce the noise external effects in the civilian sector can also be applied in the Army, especially in peacetime and in emergency conditions. However, research in the field of external effects of traffic caused by military vehicles is at the very beginning. But since these effects are more and more obvious, it is necessary to define at least the basic measures for minimizing external effects at this level of the development of the Army, such as:

- personnel training, analysis, public discussions, information,

- data monitoring,

- keeping a register of regulations and standards,

- limit exhaust gas emission,

- research and development of defense industry,

- acquisition of new and modern military vehicles,

- noise reduction, and

- resourcing and equipment in the function of traffic safety. 
In the context of this task, it is necessary to raise the awareness related to the environment and development, which in the sphere of transport must be supported by concrete facts and arguments and presented appropriately. Similarly to former campaigns for traffic safety in the Army, it would be useful to focus more attention on the problems of traffic noise and possible directions for action and define complex programs to reduce the negative effects of the transport system at all levels in the Army.

Within the information system for monitoring the use of motor vehicles in the Ministry of Defense and the Serbian Armed Forces, it is necessary to make certain adjustments that would include the collection of data necessary for the analysis of noise. There is, however, a problem of purposefulness of the application of the appropriate methodology considering the existing structure of the Army's outdated vehicle fleet. Protective measures should follow from the knowledge about noise of traffic, in the campaign to raise awareness about the importance of protecting working and living environment. The application of new engines and better fuel emission control could improve the situation in the Armed Forces in the next decade. It is necessary to accept and try to apply the experience of other armed forces and adapt them to our conditions. Also, when carrying out peacetime tasks, the Army may be required to take into account the aspects of noise impact (use of means of transport which comply with the prescribed standards relating to noise).

\section{Conclusion}

The environment had long been considered a natural inexhaustible resource to which all lay claim. However, today's society faces the necessity to choose further steps to create conditions for the preservation of working and living environment. To this end, it is necessary to finally realize that all the nations are one family and one community on the Earth with the same destiny and that it is necessary to create a sustainable society based on the respect for nature and environmental ethics with built in responsibility for future generations. To achieve this goal, it is necessary that all people accept their share of responsibility for other people, for a greater community, and especially for future generations. In this context, environmental policy is not limited to the control of pollution at the local level, but it also has a global character.

Nowadays, noise and its harmful effects are on the increase. This is confirmed by the fact that damage to hearing by noise is among the most prominent health problems in the human environment, and if other effects of noise on the human organism are added, it is clear how serious possible consequences of noise pollution can be.Therefore, it is essential for 
science and practice to find mechanisms for controlling harmful effects of noise and measures against it, which will allow the smooth progress of people's business, social, recreational, creative and other activities.

A system approach to solving complex problems of adverse noise impacts of urban traffic systems has no alternative. In order to efficiently achieve tangible results in protection against noise, it is therefore necessary that all relevant factors, besides theoretical analyses, implement adequate measures to improve protection against noise impact, which would maintain and possibly improve the overall quality of the human life. Accordingly, measures such as reducing noise at source, setting up sound barriers, setting up green buffer zones in areas between roads and residential buildings, as well as adequate soundproofing of buildings, may contribute to a significant reduction of traffic noise adverse effects.

\section{References}

Agencija za zaštitu životne sredine. 2014. Izveštaj o stanju životne sredine u 2013. godini.Beograd.

Banković, Ž. 2010. Hibridna vozila.Niš: Elektronski fakultet, Univerzitet u Nišu.

Belojević, G., Ilić, Ž.J., Paunović, K., \& Jakovljević, B. 2015. The relationship between exposure to traffic noise and resting blood pressure in children and adolescents from Belgrade. In: 10th European Congress and Exposition on Noise Control Engineering, Maastricht.

Bodin, T., Björk, J., Ardö, J., \& Albin, M. 2015. Annoyance, sleep and concentration problems due to combined traffic noise and the benefit of quiet side. Int $J$ Environ Res Public Health, 12(2), pp.1612-28. pmid:25642690

Bogojević, N., Tatić, B., \& Petrović, Z. 2011. Buka saobraćaja. U Seminar o zaštiti od buke u urbanim sredinama.Kraljevo. 27. decembar.

Djercan, B., Bubalo-Zivkovic, M., Lukic, T., Pantelic, M., \& Markovic, S. 2015. Road Traffic Noise Exposure in the City of Novi Sad: Trend Analysis and Possible Solutions. Polish Journal of Environmental Studies, 24(3), pp.977-986.

European Commission. 2015. Noise impacts on health. Science for Environment Policy, Brussels, 14.

European Commission. 1996. Green Paper: Future Noise Policy.Brussels.

European Commission Working Group 5. 2002. Inventory of noise mitigation methods.Brussels.

European Environment Agency. 2014. Noise in Europe. In Report No/2014.Luxembourg: Publications Office of the European Union.

Evropska komisija. 2011. Bela knjiga, Plan za jedinstveno transportno područje - Na putu ka konkurentnom transportnom sistemu sa efikasnim iskorišćenjem resursa.Brisel.

Ganić, E.M., Netjasov, F., \& Babić, O. 2015. Analysis of noise abatement measures on European airports. Applied Acoustics, 92, pp.115-123.

Gradski zavod za zaštitu zdravlja Beograd. 2002. Ekološki atlas Beograda.Beograd: Gradski zavod za zaštitu zdravlja. 
Gradski zavod za javno zdravlje. 2013. Kvalitet životne sredine Grada Beograda u 2012. godini.Beograd: Sekretarijat za zaštitu životne sredine Gradske uprave Grada Beograda.

Institut za ispitivanje materijala a. d. 2015. Rezime završnog izveštaja br. LAV 4814/15.Beograd.

Institut za javno zdravlje Vojvodine. 2013. Izveštaj o realizaciji projekta "Procena uticaja buke na zdravlje stanovništva Grada Novog Sada".Novi Sad: Institut za javno zdravlje Vojvodine.

Izveštaj o realizaciji G2G projekta za Srbiju, 2011, Smanjenje saobraćajne buke u Srbiji, Beograd.

Javno preduzeće Putevi Srbije. 2012. Priručnik za projektovanje puteva u Republici Srbiji.Beograd. Projekat rehabilitacije transporta, JP "Putevi Srbije".

Jokanović, I., \& Kamel, H. 2014. Methods for estimation of external costs of transport. U Zbornik radova Građevinskog fakulteta.Subotica: Građevinski fakultet Subotica, Univerzitet u Novom Sadu.

Kaplanović, S. 2012. Internalizacija eksternih troškova u funkciji obezbeđenja održivog razvoja drumskog saobraćaja.Ekonomski fakultet Univerziteta u Beogradu.

Lakušić, S., Dragčević, V., \& Rukavina, T. 2005. Mere za smanjenje buke od prometa u urbanim sredinama. Građevinar, 57(1), pp.1-9.

Official Journal of the European Communities, 2002. Directive/49/EC of European Parliament and of the Council releating to the assessment and management of environmental noise. Official Journal of the European Communities, Brussels, . L 189/12.

Pejčić Tarle, S., \& Bojković, N. 2012. Beograd, Evropska politika održivog razvoja.Beograd: Saobraćajni fakultet Univerziteta u Beogradu.

Paffen, P., Schouten, L., Bouman, I.F., \& Kamer, J. 2015. The effective planning of measures for noise abatement in relation to maintenance of roads. . In: 10th European Congress and Exposition on Noise Control Engineering, Maastricht.

Radosavljević, J.M., \& Vukadinović, A.V. 2014. Fasadne konstrukcije i njihov uticaj na snižavanje nivoa saobraćajne buke. Tehnika, 69(6), pp.925-930.

Službeni glasnik Republike Srbije, 4/2008. Strategija razvoja železničkog, drumskog, vodnog, vazdušnog i intermodalnog transporta u Republici Srbiji od 2008. do 2015. godine. JP „Službeni glasnik“, Beograd.

Službeni glasnik Republike Srbije, 88/2010. Zakon o zaštiti buke u životnoj sredini. JP „Službeni glasnik“, Beograd..

Stojanović, V.. Komunalna buka kao faktor ugroržavanja kvaliteta rada. Retrieved from: http://www.occush.vtsnis.edu.rs/knjiga_1_prezentacije/BZNR_1_Violeta_Stojanovic.pdf 2015 Sep 20.

Sygna, K., Aasvang, G.M., Aamodt, G., Oftedal, B., \& Krog, N.H. 2014. Road traffic noise, sleep and mental health. Environmental Research, 131, pp.17-24.

Vukašinović, R. 2013. Problemi buke motora i motornih vozila. U Zbornik radova 2012/2013.Leposavić: Visoka tehnička škola strukovnih studija.

Wijnant, Y.H., \& Hooghwerff, J. 2015. A model for diffracting elements to reduce traffic noise,. . U: 10th European Congress and Exposition on Noise Control Engineering, Maastricht. 
Yamamoto, K. 2015. Japanese experience to reduce road traffic noise by barriers with noise reducing devices. . U: 10th European Congress and Exposition on Noise Control Engineering, Maastricht.

Zatežić, M., Mujić, \& Biočanin, I. 2009. Saobraćaj i životna sredina u sistemu kvaliteta. . U: I International Conference "ECOLOGICAL SAFETY IN POST-MODERN ENVIRONMENT". Banja Luka.

Živković, D., Hrnjak, M., Basarić, G., \& Pešić, N. 2000. Buka, infrazvuk i ultrazvuk kod helikoptera. Vojnotehnički glasnik/Military Technical Courier, 48(6), pp.566-576.

\section{НЕБЛАГОПРИЯТНОЕ ВОДЕЙСТВИЕ ШУМА, ПРОИЗВЕДЕННОГО ТРАНСПОРТНЫМИ СРЕДСТВАМИ}

Слободан М. Старчевич ${ }^{a}$, Небойша Й. Бойович

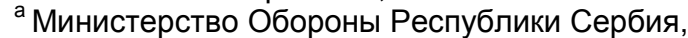

Кабинет министра обороны, г. Белград, Республика Сербия

${ }^{б}$ Белградский университет, Транспортный фракультет, г. Белград,

Республика Сербия

ОБЛАСТЬ: логистика, транспорт

ВИД СТАТЬИ: профессиональная статья

ЯЗЫК СТАТЬИ: английский

Резюме:

В данной статье представлены основные понятия и характеристики неблагоприятных воздействий транспорта на окружающую среду, с акцентом на транспортный шум, который является главным негативным фрактором транспорта в современном мире.

Приведены основные виды неблагоприятного воздействия транспортного шума на работоспособность и здоровье человека, а также причины возникновения высокого уровня шума, производимого автомобильным, железнодорожным и трамвайным транспортом.

В работе также приведен перечень стандартных мер защиты от воздействия шума, производимого транспортными средствами. А в заключении представлен краткий анализ данных воздействия транспортного шума на окружающую среду в Республике Сербия и Вооруженных Силах РC.

Ключевые слова: транспорт, шум.

\section{BUKA KAO EKSTERNI EFEKAT SAOBRAĆAJA I TRANSPORTA}

Slobodan M. Starčević ${ }^{a}$, Nebojša J. Bojovićb

${ }^{a}$ Ministarstvo odbrane Republike Srbije, Kabinet ministra odbrane,

Beograd, Republika Srbija

${ }^{\mathrm{b}}$ Univerzitet u Beogradu, Saobraćajni fakultet, Beograd, Republika Srbija 
OBLAST: logistika, saobraćaj VRSTA ČLANKA: stručni članak JEZIK ČLANKA: engleski

Paper received on / Дата получения работы / Datum prijema članka: 27. 09. 2015. Manuscript corrections submitted on / Дата получения исправленной версии работы / Datum dostavljanja ispravki rukopisa: 17. 04. 2016.

Paper accepted for publishing on / Дата окончательного согласования работы / Datum konačnog prihvatanja članka za objavljivanje: 19. 04. 2016.

(c) 2016 The Authors. Published by Vojnotehnički glasnik / Military Technical Courier (www.vtg.mod.gov.rs, втг.мо.упр.срб). This article is an open access article distributed under the terms and conditions of the Creative Commons Attribution license (http://creativecommons.org/licenses/by/3.0/rs/).

() 2016 Авторы. Опубликовано в "Военно-технический вестник / Vojnotehnički glasnik / Military Technical Courier" (www.vtg.mod.gov.rs, втг.мо.упр.срб). Данная статья в открытом доступе и распространяется в соответствии с лицензией "Creative Commons" (http://creativecommons.org/licenses/by/3.0/rs/).

(c) 2016 Autori. Objavio Vojnotehnički glasnik / Military Technical Courier (www.vtg.mod.gov.rs, втг.мо.упр.срб). Ovo je članak otvorenog pristupa i distribuira se u skladu sa Creative Commons licencom (http://creativecommons.org/licenses/by/3.0/rs/). 